\title{
COMPILER INTO GENIUS. THE TRANSFORMATION OF DICTIONARY WRITERS IN EIGHTEENTH-CENTURY FRANCE AND ENGLAND
}

\author{
Caspar Hirschi*
}

Dictionary-writers, at least such as meddle with arts and sciences, seem exempted from the common laws of Meum and Tuum; they do not pretend to set up on their own bottom, nor to treat you at their own cost.

Ephraim Chambers, 'Plagiary', in Cyclopædia (1728)

It is enriched with several useful discoveries and ingenious reflections. It is by happy geniuses who cannot treat even the best-known subjects without leaving, so to speak, their imprint on them and presenting them under an entirely new aspect.

[Anonymous], Review of the Encyclopédie's second volume, in Journal des Sçavans (1754)

THEME AND THESES

In 1757 the French essayist and playwright Charles Palissot, a man who loved Voltaire and loathed Diderot, published a collection of Little Letters on the Great Philosophes. Its first epistle was a well-timed attack on the editors of the Encyclopédie. Diderot and d'Alembert, having published seven volumes in seven years to loud plaudits and even louder polemics, were about to come under increased pressure; Damien's attempt to assassinate Louis XV at the beginning of the year had caused a tightening of censorship, and the Encyclopédie, plagued by old and new accusations, soon faced the threat of an official ban. Palissot's criticism, by contrast with that of other opponents of the Encyclopédie, was driven neither by concerns about political stability nor by the wish to defend Christianity.

* The translations in this article are by the author unless otherwise indicated. Unfortunately, due to the limited space available, it was not possible to quote the original text in the footnotes. For the same reason, secondary literature is only indicated when it directly provides facts or arguments to support the author's reasoning. The author would like to thank Harvey Chisick and Andreas Hauser for helpful criticism and valuable suggestions. 
He was anti-philosophes, not anti-lumières, and was especially appalled by the public esteem the encyclopédistes enjoyed.

At the beginning of the first letter Palissot complained that the authors of the Encyclopédie "announced the truth or what they have taken for truth with a pomp it never had before;" they adopted "a tone of authority and decision that has, until today, only belonged to the pulpit" and they introduced "a language to moral treatises and metaphysical speculations which has been condemned everywhere else as fanaticism."1 The letter went on with the reproach that the philosophes combined their pretentiousness with servile copying from the work of Francis Bacon, and after further accusations of hypocrisy and unoriginality, Palissot concluded with the statement: "I reserve for myself the freedom to think that a dictionary, as good as it might be, has never been a work of genius."

This was not the only occasion that Palissot refused to accept that lexicographers could pass for original thinkers. In the second of the Petites Lettres, which dealt with Diderot's play Le Fils naturel, he extended the argument saying that he could hardly believe in new discoveries "in a century where people who call themselves men of genius are occupied with nothing but a dictionary."3 And in his satirical play Les philosophes, which, to the great annoyance of Diderot, Rousseau and others, scored an instant success at the Comédie Française in 1760, "encyclopédie" rhymed with "génie". 4

In the end, of course, Palissot found himself on the losing side; generations of literary historians portrayed him at best as an involuntary muse of Diderot's masterpiece Le Neveu de Rameau and at worst as a mediocre enemy of progress consumed by envy of his more gifted contemporaries. ${ }^{5}$ Yet knowledge of the end of the story can hamper our understanding of its unfolding and even lead to anachronistic conclusions. If one looks at Palissot's criticism of the philosophes not from the perspective of the decades following the publication of the Encyclopédie but from the decades preceding it, one has to admit that he had a point. In their role as dictionary writers, Diderot and d'Alembert did indeed enjoy the reputation of literary geniuses - even among some of their enemies. Furthermore, they had built this reputation to a great extent through elaborate and eye-catching

\footnotetext{
1 Charles Palissot, Petites Lettres sur de grands philosophes (Paris 1757), 2.

2 Ibid., 15.

3 Ibid., 23.

4 Ibid., 27.

5 Hilde H. Freud, Palissot and Les Philosophes (Geneva 1967), 23-31.
} 
self-promotion in the first volumes of the Encyclopédie. ${ }^{6}$ And finally, by this achievement, they had completed a rapid transformation of the public image of the lexicographer: a figure long treated as a modest compiler could now be considered an original author and scholarly hero.

Palissot, therefore, as a figure of classicist tastes who venerated the age of Louis XIV, had some reason to express his bewilderment about the scholarly status of the encyclopédistes. What he was unable to understand, though, was how this transformation had taken place, and what he did not see at all was that dictionaries, despite the questionable standing of their authors, became a highly important instrument of knowledge organisation in the eighteenth century.

The rise of dictionary writers in public esteem was not a phenomenon confined to French-speaking Europe. It occurred elsewhere, too, most notably in Britain, where it culminated simultaneously with Samuel Johnson's Dictionary of the English Language. Johnson, too, was hailed as "a genius of the highest ranks" on the basis of his lexicography. ${ }^{7}$ Although Johnson fashioned himself very differently from the French encyclopédistes and although the ascendancy of earlier English lexicographers had taken place under dissimilar conditions than the careers of their French counterparts, developments in Britain and France were closely intertwined, with many articles and even a few whole dictionaries being translated from one language to another. Moreover, dictionary production in England and France was often propelled by nationalistic rivalry. English lexicographers looked to French models, and over time the French returned the compliment. Neither was as interested in the works of any other country. This certainly had to do with state politics, namely the long-term struggle between the two leading European powers for imperial hegemony. Yet there was another reason, less political and more cultural: a complementary relationship between the dictionaries produced in the two languages. While the French from the late seventeenth century onwards had the edge in language and historical dictionaries, ${ }^{8}$ the English could soon claim the

6 For my understanding of self-promotion, see Caspar Hirschi, 'Magistrate der Öffentlichkeit: Politische Selbstdarstellung aufklärerischer Gelehrter im Gewand antiker Autoren', in Johannes Helmrath and Stefan Schlelein (eds.), Macht Antike Politik? Politische Antiketransformationen in der Europäischen Geschichte (forthcoming).

7 James Boswell, The Life of Samuel Johnson, LL.D (London 1791), 2 vols., I: 163.

8 As to French language dictionaries, the most noticed and widespread were Pierre Richelet, Dictionnaire françois (Genève 1679/80 ...1693, 1710, Paris 1719, Lyon 1706, 1728, Bâle 1735); Antoine Furetière, Dictionnaire universel (The Hague and Rotterdam 1690, 1694, 1701, 1702, Rotterdam 1708, The Hague 1725, 1727); Le Dictionnaire de l'Académie françoise 
upper hand in scientific dictionaries. ${ }^{9}$ Paradoxically, Johnson's Dictionary and the Encyclopédie - the national monuments of English and French dictionaries per se-are also those most strongly influenced by foreign models.

Looking at both countries together offers an opportunity to examine the impact of contrasting systems of censorship, copyright and commerce on the self-promotion of eighteenth-century scholars occupied with similar large-scale publishing enterprises. Scholarly identities in the Age of Enlightenment, despite the intensity of international exchange between men of letters in general and between lexicographers in particular, were significantly shaped by the political cultures of their individual states. The role of compiler in late seventeenth-century France could have remarkably different implications than the same role in Britain at the same time, and so it was with the role of the original author or genius a few decades later.

This essay is guided by the following theses: firstly, the transformation of leading lexicographers into geniuses was a momentary phenomenon arising from an imbalance within the rapidly changing "economy" of knowledge production. While the acceleration of knowledge creation in the seventeenth century was concurrent with an increased veneration of scientific inventors and discoverers, the subsequent intensification of knowledge administration and popularisation did not inspire an equal re-evaluation of commentators, regulators and demonstrators of learning; on the contrary, those specialising in valuing, storing, interlinking and popularising knowledge were downgraded to servants of original thinkers or, even worse, to useless pedants. One reason for this was that originality and usefulness became more closely tied. For lexicographers, seeking the role of innovators was an attempt to overcome the chronic status problems related to the authorship of their widely used works, but it was not a durable solution because it did not properly reflect their scholarly functions and positions. Apart from a few success stories, most dictionary writers in the second half of the eighteenth century remained badly paid

(Paris 1694, 1718, 1740, 1762); Dictionnaire universel françois et latin, later known as Dictionnaire de Trévoux (Paris 1704, 1721, 1732, 1734, 1740, 1743, 1758, 1771). The two most prevalent and repeatedly translated French historical dictionaries were Louis Moréri, Le grand dictionaire historique (Lyon 1674 in 1 vol., 1681 in 2 vols.... Paris 1759 in 10 vols.), translated into English as Great Historical, Geographical and Poetical Dictionary (London 1694), and Pierre Bayle, Dictionaire historique et critique (Rotterdam 1697, 1702, 1720, Amsterdam 1730, 1740, Genève 1715, Paris 1734, Bâle 1738), translated into English and considerably extended as Historical and Critical Dictionary (London 1710).

9 John Harris, Lexicon Technicum (London 1704, 1708, 1710, 1716, 1725, 1736, 1744) and, most notably, Ephraim Chambers, Cyclopcedia (London 1728, 1738, 1739, 1741/43, Dublin 1740). 
hacks trying to portray themselves, if they had the chance at all, as genuine innovators. ${ }^{10}$

Secondly, eighteenth-century encyclopaedias have more in common with late seventeenth-century language dictionaries than with earlier encyclopaedic works, and so have eighteenth-century encyclopaedists with late seventeenth-century lexicographers. ${ }^{11}$ Throughout this period, the boundaries between encyclopaedias and language dictionaries remained blurred, not least because many of their authors had no intention of drawing a clear line. ${ }^{12}$ Antoine Furetière announced his Dictionnaire universel in 1684 as an "Encyclopaedia of the French language". The figure of the enlightened encyclopaedist, who opposed the culture of absolutism, advocated an egalitarian ideal of learning and expressed his belief in progress, was presaged in the Jesuit Dictionnaire de Trévoux of 1704, a French-Latin language dictionary. And for writers of universal scientific dictionaries, playing down the differences between language dictionary-making and their own trade facilitated an "ennobling" comparison of their works with the dictionary of the Académie française.

Thirdly, dictionaries owed their reputation much more to self-promotion by their authors than other books, because they were mostly selectively read and hardly ever completely evaluated. A lexicographer, to present himself in a favourable light, had to make use of the texts framing the main part of the book, which was the alphabetical presentation and explanation of a vocabulary. Most crucial for this purpose were Dedications, Prefaces, Introductions, Preliminary Discourses and Advertisements; they allowed authors to speak about themselves and to display their originality. Of similar importance, at least for some dictionaries, were Plans published in advance to announce the project and seek subscriptions, Subscription lists inserted at the beginning or end of the dictionary and, not least, Title pages and Frontispieces. In this respect it would be only a slight exaggeration to say that for the public image of a dictionary, its paratexts constituted the main text.

10 Robert Darnton, The Business of Enlightenment: A Publishing History of the Encyclopédie, 1775-180o (Harvard 1979).

11 There generally seems to be little clarity on what passes for an "encyclopaedia" in the medieval and early modern periods, with the consequence of very wide and varied use of the term; see Peter Binkley (ed.), Pre-modern Encyclopaedic Texts (Leiden 1997); Robert Collison, Encyclopaedias: Their History throughout the Ages (New York and London 1964), 44-113.

12 Carey McIntosh, 'Eighteenth-Century English Dictionaries and the Enlightenment', The Yearbook of English Studies 28 (1998), 3-18: 8. 
And fourthly, Johnson and the encyclopédistes, in the paratexts of their dictionaries, successfully tried to eliminate their predecessors from public memory in order to consolidate their claims of originality. Modern historians, too, have been under the spell of this strategy, devoting their attention to these two works, while largely neglecting the dictionaries published before $175^{\circ}$. Only a few have resisted the trend. ${ }^{13}$ As soon as one takes the preceding works into account, the lexicography of Johnson, Diderot and d'Alembert looks considerably less bold, whereas their selfpromotion looks even bolder.

In modern times, the Encyclopédie and Johnson's Dictionary have come to embody much more than just intellectual genius. They even star in foundation myths of modern authorship, standing for the autonomy of intellectuals vis à vis both state and church (Encyclopédie), or for writers' liberation from patronage (Dictionary). Johnson's Letter to Lord Chesterfield, written in 1755 to reject the nobleman's planned patronage of his work, has been labelled "literature's declaration of independence"14 and "the Magna Carta of the modern author."15 One has to engage in some serious misreading to come to such conclusions, and a vivid imagination is required as well to proclaim the birth of modern authorship from the spirit of lexicography. However, such narratives are attractive because they insinuate a transition from intellectual impurity to purity, from epistemic chaos to order, accomplished by single literary monuments. They prove especially powerful in an age like ours, when established literary genres, scholarly roles and concepts of authorship seem to be swept away by the Internet. Drawing a more nuanced picture of the "siècle de l'Encyclopédie" might therefore help to get a better understanding of the "Age of Wikipedia", too.

In what follows we shall first consider a comparative outline of the changing circumstances under which dictionary writers in France and England operated. Based on universal dictionaries published between 1690 and 1760 , we will then turn to the different strategies they used to modify their profiles. Among these strategies are the creation of a venerable

13 The broadest overview of English and French dictionary writing predating the Encyclopédie and Johnson's Dictionary can be found in Frank A. Kafker (ed.), Notable Encyclopaedias of the Seventeenth and Eighteenth Centuries: Nine Predecessors of the Encyclopédie (Oxford 1981), and the current state of research is represented by Richard Yeo's excellent study Encyclopaedic Visions: Scientific Dictionaries and Enlightenment Culture (Cambridge 2001).

14 William Joseph Long, Outlines of English and American Literature (Boston 1917), 165.

15 Alvin Kernan, Samuel Johnson and the Impact of Print (Princeton 1987), 105. 
genealogy of dictionary writers, the imagery of territorial expansion portraying the lexicographer as a participant in a civilising conquest, the portrayal of dictionary writers as critical commentators and as agents of enlightenment, and finally, the emphasis on lexicography as self-sacrifice for the republic of letters, the nation or humankind, rewarding the author with nothing but sickness, sorrow or persecution.

\section{The Cult of Originality and Its Victims}

In the early modern period writing and editing a dictionary was generally seen as the typical work of a compiler. According to the definition given by Antoine Furetière in 1690, a compiler was "an author who has collected and gathered several works to present them to the public, or who has collected everything that others have said on certain matters."16 The second meaning corresponded to the traditional role of a lexicographer, who was expected to reproduce the complete vocabulary of either a field of knowledge or a language, to collect all relevant data produced by other authors, and to attribute it to the right terms. There was hardly any originality applied to the task, but this does not mean that it was disparaged. Until the mid-seventeenth-century "compiler" usually was neither a word of praise nor of shame; it was rather a neutral designation of a man of letters engaged in a certain type of scholarship in which one could both excel and fail. This use was still echoed in the example given in Pierre Richelet's Dictionnaire françois of 1680: "Du Chêne, who has given us five volumes of French history, is a famous compiler."17

The widespread acceptance of the compiler as an indispensable figure corresponded to the learned culture of humanist classicism that had dominated large parts of European scholarship since the sixteenth century. By collecting and assembling material from old texts, a compiler acted as a curator and circulator of old learning, which enjoyed greater epistemic regard than recently produced knowledge, especially when attributed to classical authors. A typical literary genre of early modern compilation was the commonplace book, composed either for personal or public use, amongst others by no lesser authors than Jean Bodin and Francis Bacon. ${ }^{18}$

16 Furetière 1690 (note 8 ), unpaginated.

17 Richelet $1679 / 80$ (note 8 ), 156.

18 Ann Blair, 'Humanist Methods in Natural Philosophy: The Commonplace Book', Journal of the History of Ideas 53 (1992), 541-551. The commonplace book has also been 
Within humanist culture, the role complementing that of the compiler was the commentator, defined by Furetière as someone "who writes to explain an old or obscure book, or to make some additions or supplements to what is missing there." ${ }^{19}$ A commentator was not expected to be inventive either; quite the opposite, his task of reconstructing the original text and meaning of a literary work was meant to be guided by bookish scholarship and textual evidence. Both figures, compiler and commentator, were inclined to understate their originality. In the name of knowledge preservation, they accomplished innovations by rearrangement (compiler) and by reconstruction (commentator). Such understatement was functionally well suited to a learned culture controlled by official censorship.

Before the second half of the seventeenth century inventions and discoveries were practices mainly attributed to mechanical arts such as typography, gun-making or architecture. Already sixteenth-century humanists, who were proud of the technical innovations of their fellow countrymen, ascribed the mental qualities of ingenium and subtilitas to outstanding craftsmen and artists. ${ }^{20}$ At the same time, they were anxious to keep mechanical and liberal arts discrete and therefore constructed their own roles on different grounds. However, the classicist self-promotion of humanist scholars turned into a disadvantage when princely courts intensified their demand for artistic and scientific innovation and when the increased production of new knowledge gave way to an unprecedented belief in progress. By the end of the seventeenth century, French or English scholars enjoying the reputation of compilers had nothing much to laugh about. Meanwhile, learned commentators fared a little better, because their philological criticism of classical texts could be regarded as a practice preliminary to the "universal" criticism introduced and exercised by enlightened thinkers. ${ }^{21}$

The case for the worthlessness of compilers was forcefully advocated by Jean de la Bruyère in his widely read Caractères. In the English translation of 1713, the first of his essays, On the Manners of the Present Age, was

presented as a precursor to enlightened encyclopaedias; see Richard Yeo, 'Ephraim Chambers's Cyclopcedia (1728) and the Tradition of Commonplaces', Journal of the History of Ideas 57 (1996), 157-175.

19 Furetière 1690 (note 8$)$, unpaginated.

20 Caspar Hirschi, Wettkampf der Nationen: Konstruktionen einer deutschen Ehrgemeinschaft an der Wende vom Mittelalter zur Neuzeit (Göttingen 2005), 283.

21 This "genealogy" is still advocated by Voltaire, 'gens de lettres', in Denis Diderot and Jean le Rond d'Alembert (eds.), Encyclopédie, ou Dictionnaire Raisonné des Sciences, des Arts et des Métiers (Paris, Neuchâtel and Amsterdam 1751-1772), 28 vols., VII: 599-600: 599. 
entitled Of Polite Learning. After praising those "Artists or able Men", who "by their Genius and Invention... frequently break thro the Rule of Art to ennoble it, and thwart the common Roads, if they don't conduct them to what is great and extraordinary", La Bruyère launched an attack on those "inferior or subaltern" minds, "who seem as if they were born only to collect, register and raise Magazines out of the Productions of other Genius's." He then continued:

They are Plagiaries, Translators, or Compilers; they never think, but tell you what other Men have thought. And as the good choice of Thoughts proceeds from Invention, having none of their own, they are seldom just in their Collections, but chuse rather to make them large than excellent. They have nothing Original of their own; they know not what they learn, and learn what the rest of the World are unwilling to know; a vain and useless Science, neither agreeable nor profitable in Commerce or Conversation: Like false Mony, it has no currency; we are at once surpriz'd at their reading, and tir'd with their Company or Writing: However, the Great Ones and the Vulgar mistake 'em for Men of Learning, but the Wise rank 'em with the Pedants. ${ }^{22}$

Quoting this passage at length helps to bring out the radical dichotomy that is created here: "genius" — signifying either "natural talent" or "man of superior faculties" - is linked to true learning, noble art, useful science and agreeable conversation, whereas "compiler" is associated with mental inferiority, plagiarism, dullness, deceit, uselessness and pedantry. In between, la Bruyère reserved a place for commentators, albeit closer to those living the lowlife of compilers than to those "mounting high"; he judged criticism "a Trade, not a Science; it requires more Health than Understanding, more Labour than Capacity, and Habit than Genius." ${ }^{23}$ The dichotomy between original and unoriginal thinking was all the more fundamental, as the term "genius" reduced it to a question of natural disposition.

There is a certain irony in La Bruyère's damning of compilers as his own work, according to the older interpretation of the term, rather matched the criteria of a compilation. The French first edition of 1688 consisted of a free translation of Theophrastus' Characters supplemented with miscellaneous remarks and a few new character portraits by the author himself. There was no passage praising geniuses and condemning compilers at that stage; it was inserted in subsequent editions between 1688 and 1692, together

\footnotetext{
22 Jean de la Bruyère, 'Characters', in Works of Monsieur de La Bruyere (London 1713), 2 vols., II: $27-28$.

23 Ibid., 28.
} 
with other bits and pieces, which eventually tripled the size of what became to form the famous second part on contemporaneous persons. ${ }^{24}$

The fall of compilers into disrepute was soon reflected in dictionaries, too. The article Compilateur in the 1701 edition of Furetière's Dictionnaire universel, revised by Henri Basnage, quoted La Bruyère's harsh verdict, and so did the Dictionnaire de Trévoux, which copied the whole article from Basnage. ${ }^{25}$ Nathan Bailey defined compilation in his Universal Etymological English Dictionary, the most sold and-in terms of vocabulary-most complete English language dictionary of the eighteenth century, as "A Robbing or Plundering: Also a heaping up." ${ }^{26}$ And while Samuel Johnson's definition of compiler was rather neutral, his two examples aptly reproduced the old and new meanings of the term. From Bacon's New Atlantis of 1627 he quoted: "Some draw experiments into titles and tables; those we call compilers." And to Jonathan Swift he ascribed the sentence: "Some painful compiler, who will study old language, may inform the world that Robert earl of Oxford was high treasurer."27 Johnson actually shortened Swift's sentence with the effect that the term sounded significantly more negative than in the original. ${ }^{28}$

On the whole, when the heyday of universal dictionaries started, the standing of compilers was lower than ever before. ${ }^{29}$ It did not take long until this imbalance raised direct questions about the value of dictionaries. In the London Magazine of 1736, an anonymous author ended his essay on the Causes of the Decay of Learning with the words:

24 Jean de la Bruyère, Les caractères de Théophraste traduits du grec avec Les caractères ou les mours de ce siècle (Paris 1692), 99-101.

25 Furetière 1701 (note 8), unpaginated; Dictionnaire universel françois et latin 1704 and 1721 (note 8), unpaginated.

26 Nathan Bailey, Universal Etymological English Dictionary (London 1723), unpaginated; from 1730 onwards Bailey's dictionary was published, in gradually expanded editions, under the title Dictionarium Britannicum.

27 Samuel Johnson, 'Compiler', in A Dictionary of the English Language (London 1755), 2 vols., I: unpaginated.

28 Johnson's sentence makes the compiler seem like a pedant proclaiming banalities. This was not Swift's intention. For a comparison, see Jonathan Swift, Proposal for Correcting, Improving and Ascertaining the English Tongue (London 1712), 41: "If things go on at this rate, all I can promise your LORDSHIP is, that about two hundred years hence some painful compiler, who will be at the trouble of studying old language, may inform the world that, in the reign of QUEEN ANNE, ROBERT EARL OF OXFORD, a very wise and excellent man, was made High Treasurer, and saved his country, which in those days was almost ruined by a Foreign War and a Domestic Faction."

29 On further British authors who stressed the superiority of original over imitative composition, see Mark Rose, Authors and Owners: The Invention of Copyright (Cambridge 1993), 114-124. 
All Sciences are now chiefly comprised in Dictionaries, we want no other Keys to unlock them: There's scarce a Man of tolerable Reading, but when furnished with a good Moreri, thinks himself upon a Level with the learned of the first Rank, the Compilers of which were below those of the second. ${ }^{30}$

Here, dictionaries are directly blamed for preventing the advancement of learning. Attacks of this sort, exploiting the bad name of compilers, were a threat to both the status of lexicographers and the epistemic authority and long-term success of dictionaries. After all, universal dictionaries owed much of their public appeal to the promise of sorting the world of knowledge in a time of accelerating change and information overload: language dictionaries held out the promise of fixing speech and writing by indicating the right use of words, and scientific dictionaries claimed to reduce the glut of knowledge to digestible portions by separating the wheat from the chaff, thereby facilitating future innovations. ${ }^{31}$ These were ambitious pledges and they had to be backed by epistemic authority in order to be credible. Authorship linked to the meagre talents and immoral manners of compilers could only offer proof of the contrary. Creating a favourable image of lexicographers was all the more important as universal dictionaries were major investments for publishers and often had to be co-funded by wealthy subscribers or patrons, who naturally had no incentive to be associated with works of dubious provenance. ${ }^{32}$

\section{The Impact of Copyright AND Censorship}

The situation for writers and publishers of dictionaries was further complicated by the mechanism of copyright legislation in Britain and censorship in France. The two systems had quite opposite effects. British copyright legislation was first introduced by the Act for the Encouragement of Learning in 1710 to replace the Licensing Act, which had been abandoned, together with pre-publication censorship, fifteen years before. ${ }^{33}$

\footnotetext{
30 The London Magazine, and Monthly Chronologer 5 (1736), 84.

31 Yeo 2001 (note 13), 141-144.

32 On publishing dictionaries by subscription, see ibid., 46-58; on problems of epistemic authority in relation to the subscription business in general, see Adrian Johns, The Nature of the Book. Print and Knowledge in the Making (Chicago and London 1998), 450-453.

33 After the end of pre-publication censorship, authors could still be legally persecuted for libel, blasphemy, sedition and treason, but actual cases of severe punishment became increasingly rare in the course of the eighteenth century and always were on a small scale in comparison to France. Edward G. Andrew, Patrons of Enlightenment (Toronto 2006), 28 and $54-55$.
} 
It established a legal understanding of authorship that was tied to the notion of an immutable work created by original invention. The act guaranteed the copyright owner of an unpublished work the "sole Right and Liberty of printing" for fourteen years plus another fourteen years if the author was still alive at the end of the first period; it further conferred the same exclusive rights to copyright owners of a previously published book for 21 years. Although this piece of legislation was obviously not meant to target dictionaries, it added to the pressure on lexicography. ${ }^{34}$ Dictionary writers either reacted by defending their "own avowed practice" of copying from each other as a legal exception, or they pretended to have invented almost everything themselves, therefore meriting the name of author, not of compiler. ${ }^{35}$ Dictionary publishers, meanwhile, who claimed a copyright on their titles, faced the uncertainty of what was meant by the licence "to Print or Reprint the same". ${ }^{36}$ As a matter of fact, reprints of dictionaries were generally far from identical with the original edition, and revisions and additions were often not accomplished by the original author. Successful titles could, years after the author's death, grow from one to ten volumes and even change confessional or national alignment. ${ }^{37}$ In such a process the author's name mutated from originator to brand. And because "improvements" and "corrections" were used as selling

34 Rose 1993 (note 29), 137.

35 Chambers 1728 (note 9), vol. 1, XXIII. For a nice example of an ostentatious claim of originality, see Yeo 2001 (note 13), 212-213 and 229.

36 An Act for the Encouragement of Learning (London 1710), 1 (italics by the author). Quite a few publishers did not officially register their dictionaries in the decades following 1710, because the costs were high and the actual protection was still low. See Yeo 2001 (note 13), 225-228.

37 Moréri's Grand dictionnaire historique was launched by the author as a staunchly Catholic work in one volume; after his death in 1680 it was turned into a multivolume Protestant dictionary by the Dutch Calvinist Jean Le Clerc in 1691, then "reconverted" to Catholicism by a Parisian publisher in 1699. In 1701, the English translator of Le Clerc's version, Jeremy Collier, found it "necessary to melt down some part of the English History and throw it into a new Form." By 1759, the Parisian edition had grown into ten volumes. A similar fate was in store for Furetière's Dictionnaire universel, whose first edition was already posthumously published, then Protestantised by Henri Basnage in 1701 and reCatholicised under the different title of Dictionnaire de Trévoux in 1704. And when Pierre Bayle's Dictionaire historique et critique was translated into English by Johnson's friend Thomas Birch between 1734-1741, he added hundreds of British biographies to the original. See Jeremy Collier, 'The Preface', in Louis Moréri, The Great Historical, Geographical, Genealogical and Poetical Dictionary (London 1701), unpaginated; Arnold Miller and Louis Moréri's Grand dictionnaire historique, in Kafker 1981 (note 13), 13-52: 18-19; Dorothea Behnke, Furetière und Trévoux. Eine Untersuchung zum Verhältnis der beiden Wörterbuchserien (Tübingen 1996); Anne McDermott, 'Johnson's Dictionary and the Canon: Authors and Authority', The Yearbook of English Studies 28 (1998), 44-65: 47. 
points in the advertisements of new editions, the changes could hardly be overlooked.

Dictionary publishers therefore could not have been too surprised that their copyright was soon officially challenged. In 1737, when Ephraim Chambers prepared a recast of his successful first edition of the Cyclopedia, a bill was introduced in Parliament "containing a clause to oblige the publishers of all improved editions of books, to print their improvements separately." This would have been a legally satisfying, though commercially harmful solution to the copyright issue at stake. Chambers abandoned the recast, although the bill, after passing the House of Commons, was thrown out in the Lords. The second edition of 1739 only contained some alterations and additions - and a new Advertisement stressing how much "the booksellers were alarmed" with the proposed bill. ${ }^{38}$ Once more, dictionary producers slipped through the legal net, but the issue remained largely unresolved.

In France, dictionary producers of the early eighteenth century had quite a different problem. As elsewhere on the continent, state licensing and official censorship remained in place. While the British copyright system encouraged self-promotion by authors as inventors and contributed to a literary culture overstating originality, a censorship system traditionally did the contrary. Censors, too, depended on an understanding of authors as originators, albeit not to reward but to punish them. As a consequence, writers had every reason to obliterate traces of original thinking and to stick to their traditional roles of compiler or commentator. Indeed, during the seventeenth century, original or heterodox thinkers often hid behind the voices of other authors. The fall of compilers into contempt therefore had a rather paradoxical effect: it became a threat to original and heterodox thinkers.

Under these circumstances, dictionary writers had basically three options. They could resist the general trend by combining the traditional roles of compiler and commentator, claiming to do a useful job of broad criticism without expecting any reward; in so doing they appeared as humble agents of progress and could even continue to play the conventional game of hide and seek with censors. This was the role taken by Pierre Bayle in his Dictionnaire historique et critique of 1695 . The second option

38 Chambers 1739 (note 9), unpaginated; John Nicols and Samuel Bentley, Literary Anecdotes of the Eighteenth Century (London 1812), vol. 5, 659; Francis Espinasse, 'Chambers, Ephraim (1680?-1740)', in Oxford Dictionary of National Biography, URL: http://www .oxforddnb.com/view/article/5070 (accessed 05.08.2009). 
was to renounce any personal exposure and responsibility by publishing anonymously, which offered the opportunity to fish out of other works whatever seemed suitable. This was the way chosen by the Jesuit editors of the Dictionnaire de Trévoux in 1704, who generously helped themselves to Henri Basnage's revision of Furetière's Dictionnaire universel. They went unpunished in France, but in Holland, where Basnage's publisher enjoyed a privilege on Furetière's reprints, two hundred copies of the dictionary were seized, legally condemned as counterfeits and sent back to France. ${ }^{39}$ The third option was to make a virtue of necessity and play a high risk game by openly claiming originality, in combination with the display of willing acceptance to be persecuted. Indeed, in a capricious censorship system such as the French one, the role of genius came with a free pass to the virtue of the persecuted. This was the model adopted by Diderot and d'Alembert, and, early on, it was accepted and exploited by some critics, whose emphasis on their genius was meant to sound like an alarm bell. A long review of the Encyclopédie's first volume in the Journal des Sçavans summarised its message as follows:

For a long time no book has come out that was as well-shaped, as philosophic, as full of wit and sagacity and that marks such superior genius. But we are obliged to warn that this work has defects and contains even dangerous things in important matters, which watchful journalists must not be silent about. ${ }^{40}$

Diderot and D'Alembert immediately saw the danger of such poisoned praise and tried to silence their journalist critics by repeated interventions with high state officials and by reiterated counterattacks in newly published dictionary volumes. ${ }^{41}$ From the start, they experienced both the upsides and downsides of genius lexicographers in a censorship system, whereas their publishers, who usually profited from the Parisian monopoly created by the French licensing practice, had to accept an even greater amount of insecurity than was already present in the business of dictionary-making. ${ }^{42}$

39 On top of this, the holder and importer of the copies, the bookseller Jean Louis de Lorme, was fined 400 florins. Behnke 1996 (note 37), 129.

40 Journal des Sçavans (1751), 617-627: 625.

41 On d'Alembert's letter to d'Argenson, see Ronald Grimsley, Jean d'Alembert (1717-83) (Oxford 1963), 27-28; on Diderot's feud with Abbé Berthier, the editor of the Journal de Trévoux, see John N. Pappas, Berthier's Journal de Trévoux and the Philosophes (Geneva 1957), 166-196.

42 On the long-time effects of the French licensing policy over the eighteenth century, see Raymond Birn, 'The Profits of Ideas: Privileges en Librairie in Eighteenth-Century France', Eighteenth-Century Studies 4 (1971), 131-168. 


\section{CAesar the Lexicographer, SAmuel the ConQueror}

Having outlined the cultural and structural conditions which forced eighteenth-century lexicographers to remake the traditional role of compilers, we can now turn to the self-promotion strategies they developed to underpin their epistemic authority. A rather conventional but effective approach was to create a venerable lineage of dictionary writers. Constructing a genealogy helped to raise one's profile in the company of past literary protagonists; it made one's work appear as a continuation or even culmination of a long and noble endeavour; and it could elegantly block out unwelcome competitors in the field. An early example of this was given by the most prestigious dictionary authorship possible in the late seventeenth century, the Académie française. In the preface of the Dictionnaire's first edition, published in 1694, the Immortals emphasised that "enlightened minds", contrary to the "vulgar", wanted to know "the different ideas on which our words form":

This is why several great personalities became very seriously attached to the study of words. The founder of the Roman Empire, Julius Caesar, in the middle of his most important endeavours, composed two books of observations on the Latin language, entitled Of Analogy, which he addressed to Cicero... Charlemagne, king of France and founder of a new empire worked as well on the embellishment of his language which he reduced to certain rules and of which he composed a grammar himself. ${ }^{43}$

Identifying the archetype of the academy lexicographer as imperator doctus was a central element of a wider plan to present the Dictionnaire as an imperialist enterprise adding to national glory. Other elements of the plan will be detailed below; here it suffices to point out the role attributed to Charlemagne as founder of both a distinctively French Empire and lexicography. For this, the academicians merely needed to discreetly obscure the fact that the Carolingian sources, while themselves exaggerating the education of the king of the Franks, had left no doubt that "his language" was Germanic. ${ }^{44}$ The presentation of lexicography as a noble task originally executed by emperors and permanently reserved for "persons of the first quality" helped as well to demonstrate that the French academicians played in a higher league than their contemporary competitors, Richelet and Furetière, whom the preface did not mention at all.

43 Preface in Le Dictionnaire de l'Académie françoise 1694 (note 8), I: fol. eii v-eiii r.

44 Hirschi 2005 (note 20), 316-318. 
The dictionary of the French Academy was a mixed blessing for later lexicographers; they profited from the prestige the academicians brought to dictionary writing, but they lacked the epistemic authority to fashion themselves in a similar way. What they could do was to openly challenge the Dictionnaire in order to elevate themselves to an equal level. Chambers, who did not shy away from such an attempt, invented an even longer genealogy of lexicographers. ${ }^{45}$ His self-promoting was split into two rather contrasting narratives, one very humble and one quite lofty. The genealogy belonged to the latter. After supposing that the earliest dictionary writer might have been just "some little grammarian", he brought forward "a more probable" assumption, that lexicography's origins lay

in the early days of the Phoenician or Egyptian sages, when Words were more complex and obscure than now; and mystic Symbols and Hieroglyphics obtain'd; so that an Explication of their Marks or Words, might amount to a Revelation of their whole inner Philosophy: In which Case, instead of a Grammarian, we must put perhaps a Magus, a Mystes, or Brachman at the head of Dictionaries. ${ }^{46}$

Chambers here drew on early modern neoplatonists, who were sure to have found the roots of Christian philosophy in the prisci theologi of ancient Egypt and Asia-reputed polymaths who excelled in all fields of study.

After his first edition had proved an instant success and he had been amply rewarded with $£_{500}$ by his booksellers and a fellowship of the Royal Society, Chambers translated the profile of the original lexicographers to the present. The result, outlined in his Considerations for a second edition, reflected the rapid rise of a former globe maker's assistant to literary fame. A dictionary writer, according to Chambers, "must have a compass of learning more universal than was ever found in the most celebrated Polyhistors, an Eratosthenes, Varro, or Bacon;... have more Reading than a Leibnitz or Le Clerc; more Reflection than a Hobbs, Malebranche, or Locke" and so on. Fully identifying with this profile, Chambers proudly announced that the recast Cyclopcedia would "furnish the best Book in the Universe; and abundantly indemnify us in the Want of what other

45 At the beginning of the preface, Chambers brought the same argument forward that later contributed to Johnson's fame-minus the display of nationalistic chauvinism: he claimed to have accomplished more on his own in a shorter period of time than the members of the "Academy della Crusca" and the "French Academy" together. Chambers 1728 (note 9), vol. 1, I; Johnson's version, as told long after his death by Boswell 1791 (note 7), I: 101.

46 Chambers 1728 (note 9), vol. 1, XXI. 
Countries are so fond of-Royal, Imperial, Caesarian, and Ducal Academies, Palatine Societies, and the like."47

Diderot's and d'Alembert's recourse to famous names was not less highflown but more sophisticated. One of their main goals was to downplay Chamber's influence. The Encyclopédie not only started as a translation project of the Cyclopcedia, it also carried over Chamber's most important innovation-the combination of a systematic with an alphabetical arrangement of knowledge, purportedly linked by cross-references at the bottom of most entries. ${ }^{48}$ D'Alembert followed Chambers' model, too, when representing the system of knowledge in the form of a tree divided into branches. Instead of acknowledging these dependences, he introduced Chambers as not much more than a translator of French dictionaries, who would have only "excited the indignation of savants and the outcry of the public" were he to be translated back into French, and he maintained that "nothing is more different" from his tree of knowledge than the one by Chambers. ${ }^{49}$ The title of the official forerunner to the Encyclopédie was bestowed upon "the Chancellor Bacon", and d'Alembert indeed shaped his tree along the lines of Bacon's division of learning from 1605 (fig. 1). This conveyed the impression that the encyclopédistes did not follow other lexicographers, but figures of the highest originality. How effective this strategy was can be seen in a review of the second volume by a journalist of the Journal des Sçavans, who this time described the editors as "happy geniuses", highlighted their "useful discoveries", praised their contribution to "the glory of the nation" and especially applauded them for integrating cross-references to the alphabetical entries-"which has not been attempted until now." 50

Yet, drawing on a 150-year-old model in order to reproduce the present state of affairs came at a price. ${ }^{51}$ D'Alembert's preliminary discourse ran into inconsistencies and presented a monstrous graph in comparison to which Chambers' tree of knowledge looked easily accessible (fig. 2). This

47 Ephraim Chambers, Some Considerations Offered to the Publick, Preparatory to a Second Edition of Cyclopcedia (s.l., s.a.), 3; Robert DeMaria Jr., Johnson's Dictionary and the Language of Learning (Oxford 1986), 5-6.

48 Yeo 2001 (note 13), 211.

49 Jean Le Rond d'Alembert, 'Discours préliminaire', in Diderot and d'Alembert 17511772 (note 21), I: i-xlv: xxxv; id., 'Observations sur la division des sciences du Chancelier Bacon', ibid., li-liv: li.

50 Journal des Sçavans (1754), 84-91: 85.

51 Robert Darnton, 'Philosophers Trim the Tree of Knowledge: The Epistemological Strategy of the Encyclopédie', in id., The Great Cat Massacre and other Episodes in French Cultural History (New York 1985), 191-213: 201. 


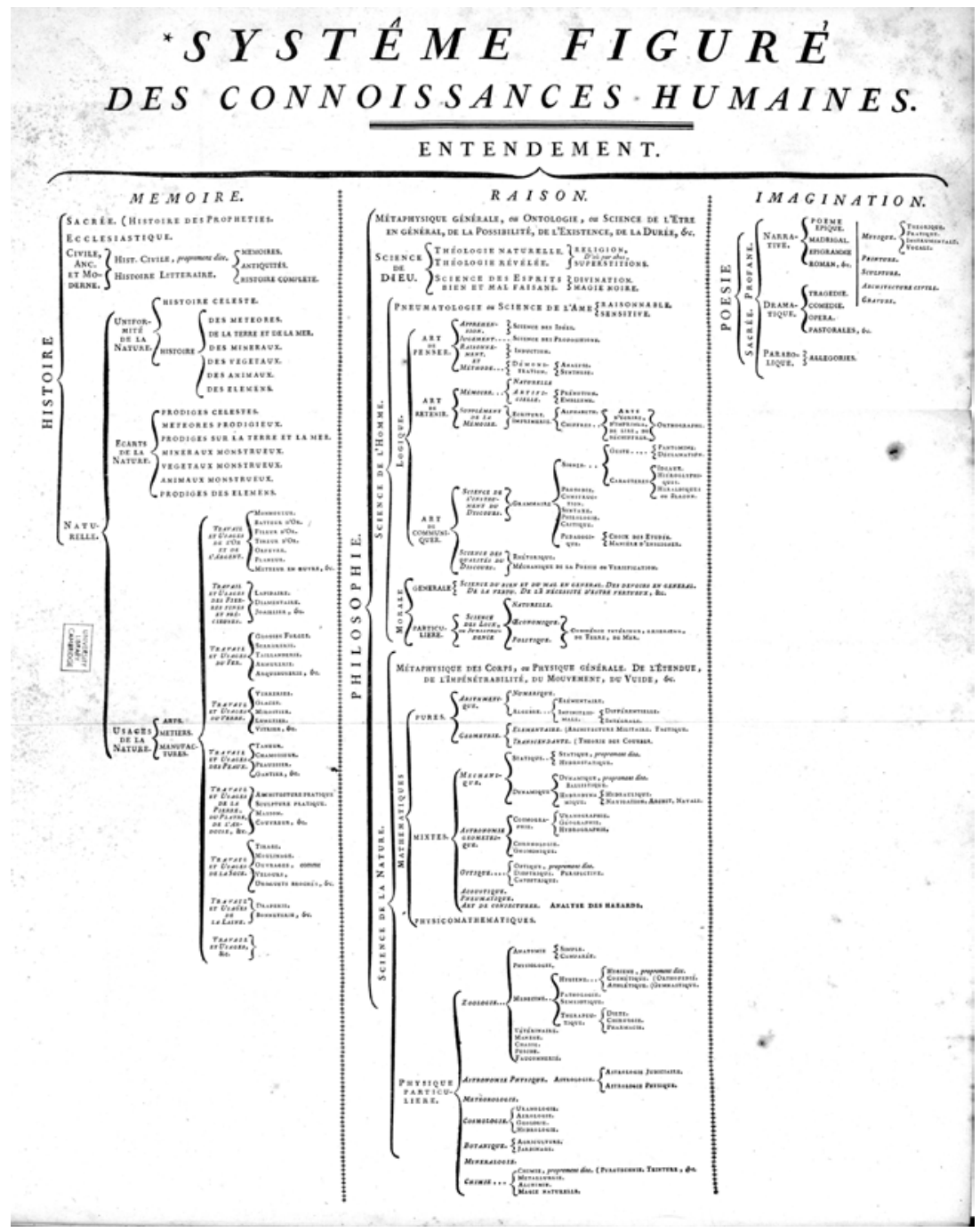

Fig. 1. "Systême figuré ses connoissances humaines", from: Denis Diderot and Jean le Rond d'Alembert (eds.), Encyclopédie, ou Dictionnaire Raisonné des Sciences, des Arts et des Métiers, vol. 1 (Paris 1751). 


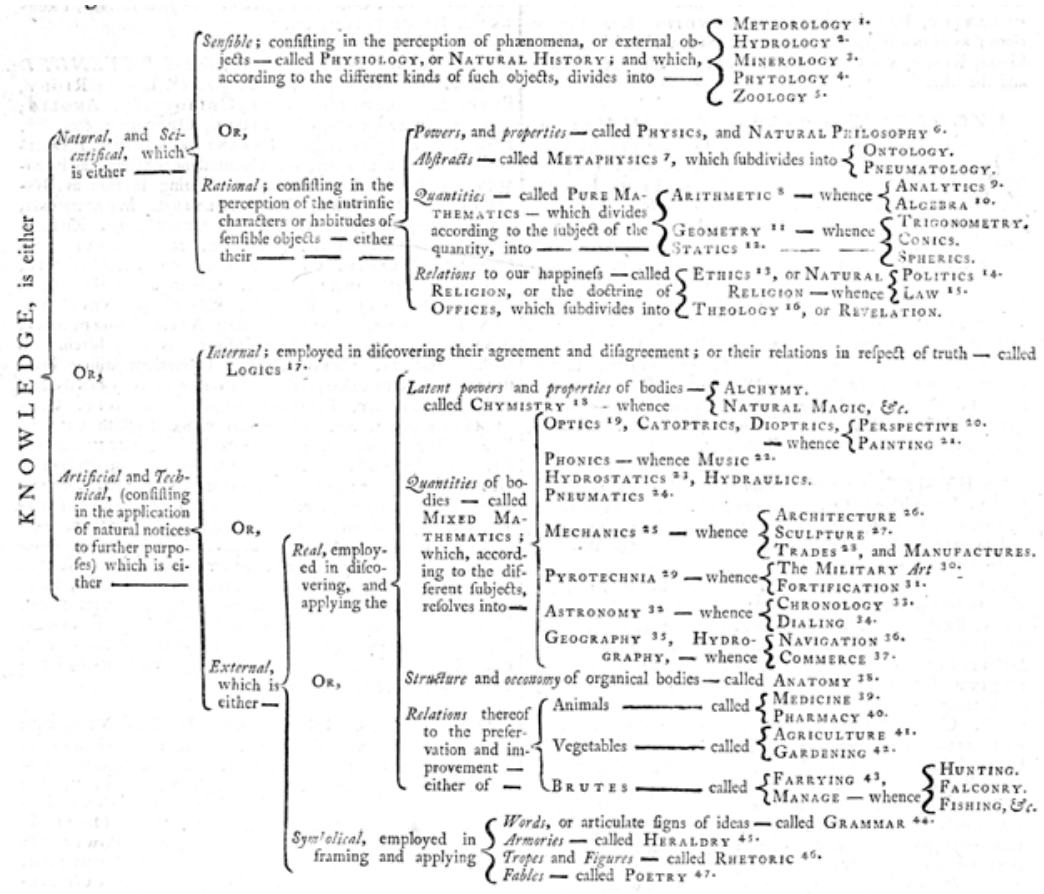

Fig. 2. Tree of knowledge, from: Ephraim Chambers, Cyclopcedia (London 1728).

did not escape the editors' notice, and Diderot, in the entry Encyclopédie a few years later, felt obliged to answer the question of why Chambers' encyclopaedic order was "so perfect and regular." Topping d'Alembert's condescending attitude he explained, without even mentioning Chambers' name, that the "English author" had "invented nothing" and was only a "labourer who ploughed his furrow, shallow, but even and straight." 52

In terms of adorning themselves with great names, Diderot and d'Alembert introduced a new dimension. They picked their personnel not only from the past, but also from the present. What enabled them to do so was their attempt to overcome the problem of epistemic authority by designing the Encyclopédie as a work written by a "society" of highly ranked expert contributors. Diderot showcased Voltaire as one of the

52 Further down, Diderot did call Chambers by name-as an example of "a bad author"; Denis Diderot, 'Encyclopédie', in Diderot and d'Alembert 1751-1772 (note 21), V: 635-648A: 641 A. 
"men of letters of the highest reputation" who "have deigned to send us pieces of their work." 53 D'Alembert proudly announced Buffon as author of the article Nature on the first page of the second volume, albeit somewhat prematurely, as the famous naturalist would never contribute to the Encyclopédie. And he composed a lengthy eulogy — a practice typical of academies - to Montesquieu in volume five, stressing his close alignment to the Encyclopédie and his suffering from similar attacks by "these authors without talent." 54

Palissot, who had composed an Eloge of Montesquieu himself, was furious to see the great man posthumously lined up with the philosophes without having left behind anything for the Encyclopédie but a short draft of the article Taste [Gout]. ${ }^{55}$ His attempt to expose d'Alembert's praise of Montesquieu as an act of usurpation touched on a crucial aspect of the image campaign by the encyclopédistes, but missed its full impact. In order to present the dictionary as a collaborative work by the leading exponents of different fields, the editors hid much of the actual authorship from the public. Most contributors, among them many unknown clerics and hacks, remained anonymous and the bulk of the work was finally done by a handful of scholarly all-rounders. In other words: the authorship represented in the Encyclopédie was very different from the people who wrote it. A long-term effect of this successful branding by Diderot and d'Alembert is that even today, and despite various detective efforts by modern historians, the authors of about two-fifths of the articles in the Encyclopédie are still unknown. ${ }^{56}$

To imagine lexicographers participating in a conquest must have given a more dynamic impression than to visualise them merely as the heads of a venerable genealogy. Here, too, the Académie française set the tone. ${ }^{57}$ In the dedication to Louis XIV, the academicians introduced their work as a cultural complement to the king's military campaigns. The French language, they argued, had been dominating Europe thanks to the king's superior power. "While we apply ourselves to embellish it, your victori-

\footnotetext{
53 Ibid., 645 .

54 Jean le Rond d'Alembert, 'Eloge de M. le Président de Montesquieu', in Diderot and d'Alembert 1751-1772 (note 21), V: iii-Xxviii: xiv.

55 Palissot 1757 (note 1), 7-10.

56 Darnton 1979 (note 10), 512.

57 Of course, the academicians had predecessors in this regard, too, the most notable an outcast from their own body: Furetière, in the dedication of his Essai d'un Dictionnaire Universel (Paris 1684), fol. ai v-aii r, already linked his Encyclopédie de la langue françoise to the Sun King's conquests, although without specifying the relation between the two.
} 
ous arms pass it on to the foreigners; we facilitate their understanding of it by our work, and you make it necessary by your conquests." 58 The academicians portrayed themselves as a functional elite providing the king an expert service to consolidate his military expansion. ${ }^{59}$ And they presented the Dictionnaire as a literary enterprise suited to the monarch's hegemonic aspirations.

Later lexicographers took up the motif of territorial expansion-and turned it into a metaphor. Chambers, in his dedication to George II, declared the Cyclopcedia "an Attempt towards a Survey of the Republick of Learning, as it stands at the Beginning of Your Majesty's auspicious Reign." He then continued:

We have here the Boundary that... separates the known, from the unknown Parts of the Intelligible World. Under Your Majesty's Princely Influence and Encouragement, we promise our selves this Boundary will be removed, and the Prospect extended far into the other Hemisphere.-Methinks I see Trophies erecting to Your Majesty in the yet undiscover'd Regions of Science; and Your Majesty's Name inscribed to inventions at present held impossible! 60

During the period when Britain rose to become the world's dominant colonial power, Chambers described the changes in science as a conquest on a global level. However, although he stressed its dependence on royal patronage and its service to royal glory, he did not link the expansion of science to the expansion of the British state. The image of conquest now expressed the universal progress of learning, and the encyclopaedia represented a map of the current state of universal knowledge. Chambers himself, in the dedication to the king, did not appear as a conqueror, but as a civiliser behind the frontlines of scientific discovery, establishing the territorial unity of learning and thereby enabling new expeditions into unknown territory.

A further step was taken by Samuel Johnson, who did not settle for the title of describer of a conquered territory. He preferred the role of conqueror. In his Plan of an English Dictionary addressed to Lord Chesterfield in 1747 , he described the challenge ahead of him:

\footnotetext{
58 Epistre, in Dictionnaire de l'Académie française 1694 (note 8), I: fol. aiii r.

59 For my understanding of the term functional elite, see Caspar Hirschi, 'Die Erneuerungskraft des Anachronismus: Zur Bedeutung des Renaissance-Humanismus für die Geschichte politischer Öffentlichkeiten', in Martin Kintzinger and Bernd Schneidmüller (eds.), Politische Öffentlichkeit im Spätmittelalter (forthcoming).

60 Chambers 1728 (note 9), vol. 1, unpaginated.
} 
When I survey the Plan which I have laid before you, I cannot, my Lord, but confess, that I am frighted at its extent, and, like the soldiers of Cæsar, look on Britain as a new world, which it is almost madness to invade. But I hope, that though I should not complete the conquest, I shall, at least, discover the coast, civilize part of the inhabitants, and make it easy for some other adventurer to proceed farther, to reduce them wholly to subjection, and settle them under laws. ${ }^{61}$

Subjecting and civilising complete barbarians was a rather bold image for a project in a field of work already treated by more than a dozen lexicographers, but it went nicely with the later myth that Johnson had composed the "first English dictionary." Johnson did not go as far as to claim Caesar's place explicitly, but as he planned his lexicographic conquest as a single author, his comparison implicitly amounted to him standing for the general and the army together. Johnson still framed his Plan as a letter to his-then wished-for-patron, but already at this early stage he fashioned himself as an autonomous scholar who planned and completed his endeavour on his own.

\section{The Virtuous Rubbish Collector, the Enlightened Advocate}

Most dictionary writers combined different narratives of quite contradictory content to fashion themselves as worthy scholars, thereby proceeding almost in the sense of Lévi-Strauss' concept of bricolage. ${ }^{62}$ Another widespread approach was to staunchly stick to the title of compiler, to enrich it with the critical renown of the commentator and to turn it all into a display of virtuous humility. The founding model was developed by Pierre Bayle. From the beginning, it was meant to oppose the long-awaited dictionary of the French Academy, which demonstrated its distinction by limiting its vocabulary to polite speech and writing. In the anonymously published Project and Fragment of a Critical Dictionary, Bayle advertised his book as "a collection of the rubbish by the republic of letters." ${ }^{3}$ He replaced the aesthetic purism of the French Academy with an epistemic purism, promising to clean up the errors that obstructed the pursuit of understanding. As a major source of errors, he identified his principal competitor Moréri's Grand dictionaire historique. The plan was not addressed to a potential

61 Samuel Johnson, The Plan of an English Dictionary (London 1747), 33.

62 Claude Lévi-Strauss, La pensée sauvage (Paris 1962), 32.

63 Pierre Bayle, Projet et Fragmens d'un Dictionnaire critique (Rotterdam 1692), unpaginated. 
patron, but to a fellow scholar, who was warned that he could find himself in the book, too, in case "some mistake has escaped you." Bayle tried in this way to meet his ideal of the republic of letters as an independent community of mutually critical friends. Eventually, his dictionary proved to be more than a collection of mistakes, but the Preface remained a deft exercise in self-denial. Bayle, by then one of the most respected and best connected men of letters throughout Europe, assured his readers that he had only cared to compile, and he equated himself to "Subaltern Officers, or even common Soldiers" who criticised their generals for some mistakes while acknowledging that they were "infinitely Inferior in Capacity as well as in Rank." 64 Working on the dictionary, he mentioned, cost him four years of hard labour and repeated sickness. Had he not been pushed by his publisher, he would have issued it anonymously because "nothing seem'd to me more noble than to shew in all the Services that are done to the Publick, the same Disinterestedness that the Gospel prescribes in Works of Charity." About those who would not believe him, Bayle remarked:

They'll think that my Scruples were grounded upon the little Honour that is to be got by appearing at the Head of a large Compilation, which they'll call a Common-shore of Collections [égout de recueils], a Rhapsody of a Transcriber, \&c. Of all the Employments, will they say, that can be had in the Commonwealth of Learning, there is none so contemptible as that of Compilers: they are the Drudges of great Men; and indeed they are not useless. ${ }^{65}$

Bayle's insistence that he was doing a useful job of extremely low standing came in a tone of authority and aplomb that elegantly undermined his explicit message. Talking at length about himself served the purpose of presenting the author, not the work as an original, and gaining the status of a selfless individualist, stubbornly bucking the trend in order to benefit the republic of letters.

Bayle's self-promotion inspired quite a few lexicographers, especially on the other side of the Channel. John Harris, in his Lexicon Technicum of 1704, positioned himself against the French academicians as well, bringing forward the utilitarian argument that he would counter their "bare Explication of Terms of Art" with an empiricist approach using first-hand observation and presenting cuts and figures. ${ }^{66}$ Chambers had recourse to

64 Preface in Bayle 1697 (note 8), 7; the translation follows the first English edition of 1710 (note 8), unpaginated.

65 Ibid., 11; preface to the first French edition in Bayle 1710 (note 8), unpaginated.

66 Harris' depiction of the Dictionnaire de l'Académie française could as well have been inspired by the preface to the first edition of Antoine Furetière's Dictionnaire universel, 
Bayle, when he tried to uphold the lexicographer's right to compile and when he took a few steps on the rhetorical road of humility. ${ }^{67}$ It was Johnson, however, who owed Bayle the most. Already at the outset of his Plan he stressed that his work was "generally considered as drudgery for the blind." ${ }^{6}$ Eight years later, the dictionary's Preface started with a depiction of lexicographers as "unhappy mortals", whom mankind considered "doomed only to remove rubbish and clear obstructions from the paths through which Learning and Genius press forward to conquest and glory." And it ended with the remark that Johnson had completed his work "amidst inconvenience and distraction, in sickness and in sorrow." 69

Johnson's self-promotion has always enjoyed great credibility because of his well-documented ordeal during the dictionary's production. Yet, when Johnson made his bitter remarks about the life of lexicographers, Ephraim Chambers had, courtesy of his Cyclopaedia, already been peacefully at rest in Westminster Abbey for fifteen years - the most prestigious address for a dead English author. Johnson, who, according to Boswell, claimed to have based his literary style on Chambers' "Proposal for his Dictionary", could hardly have overlooked the anachronism of his role play. ${ }^{70} \mathrm{He}$ anticipated correctly, though, that imitating and exaggerating an outdated model developed sixty years earlier could catapult him to even greater fame if his dictionary proved a success. When it did, his selfportrayal as an unrecognised hero sacrificing himself for the English language was transformed into a "robust genius, born to grapple with whole libraries."71

In France, Bayle is often seen as the pivotal lexicographic precursor to the encyclopédistes, mostly because his Dictionnaire served a critical function and challenged Christian orthodoxy. The self-promotion of the encyclopédistes, though, could hardly have been more different from Bayle's.

whose anonymous author is also believed to be Pierre Bayle. There, he limited the function of the Academy dictionary to "fixing the fine minds who have a panegyric to write, a play, an ode, a translation, a history, a moral treatise or such other nice books." Preface in Furetière 1690 (note 8), unpaginated; John Harris, 'The Preface', in Lexicon Technicum 1708 (note 9), vol. 1, unpaginated. Questioning Bayle's authorship of Furetière's preface: Behnke 1996 (note 37), 44.

67 On Bayle's influence on Chambers, Yeo 2001 (note 13), 42-46; for an example of Chambers' defence of compilers see the quotation at the head of this article.

68 Johnson 1747 (note 61), 1.

69 Samuel Johnson, 'Preface', in A Dictionary of the English Language 1755 (note 27), I: unpaginated.

70 Boswell 1791 (note 7), I: 119.

71 Ibid., 47. 
In constructing lexicographers as representatives of the Enlightenment, other writers had done more preliminary work, some of which one might not initially expect such as the anonymous Jesuit authors of the Dictionnaire de Trévoux. While copying most of their alphabetical entries from Basnage's edition of Furetière, they composed a long preface in which they advertised their work in an astonishingly advanced way.

Once again, the dictionary of the French Academy served as the point of departure. The Immortals had propagated the ideal of a cultural standstill, using the argument that the French language had, under the Sun King's reign, reached a "glorious point of immutability", which was to be fixed forever by their dictionary. ${ }^{72}$ Furthermore, they had announced that they would not include citations from literary works to exemplify the right usage of words because many of "our most famous orators and our greatest poets" contributed to the work. This was not completely accurate, as the prestigious authors within the Academy had generally kept their distance from the dictionary project, while some minor members had brought it forward. However, there was hardly a better way to prove not to be a compiler than by declaring other authors irrelevant for the task. ${ }^{73}$

The Jesuits answered the academicians' display of authority with an elaborate reflection on the relation of authors and readers, which they compared to that between legal authorities and citizens. First, they distinguished two types of dictionary authors, those officially recognised as "the most versed in language" and those acting as "private individuals" [simples particuliers-in legal terminology persons without public functions]. The academicians were consigned to the former category and all others - "Richelet, Furetière etc." - to the latter. While the academicians enjoyed every power to declare their understanding of words as the correct one, the private individuals, "as enlightened as they might be", lacked "the authority to decide on their own." Therefore, they were compelled to cite examples from canonical texts, whereas the academicians were entitled not to cite at all. Drawing an intermediate conclusion, the Jesuits declared:

In this respect, one has to regard the Academy as a sovereign court that has the right to pass sentences without being forced to render an account; the others, instead, can only be seen as advocates whom one consults and who

\footnotetext{
72 Epistre in Dictionnaire de l'Académie françoise 1694 (note 8), fol. aiii r.

73 Preface ibid., unpaginated.
} 
are only credible as far as they are predicated on good reasons, or on true testimonies. ${ }^{74}$

After associating the two types of dictionary writers with different legal roles, the Jesuit authors turned to the readers, asking which type they might prefer. The answer was predictable - they would go with those who cite-but the explanation was bold, voicing thinly veiled criticism of the Sun King's authoritarian regime. The public, they said, preferred citations because of

the natural pride of the human mind, which does not like to be controlled, and which suffers impatiently if one wants to subject it and act sovereignly over it, by imposing absolute laws without letting it know the motives and reasons. This kind of blind submission, which it thinks is demanded of it, has something that shocks and appals it; in contrast, it is agreeably flattered by the deference and attention, which those pay to its wit [lumières] who put nothing forward without backing it up with solid proof and good testimony. ${ }^{75}$

Here, the imagery shifted from the legal to the political stage, and the promotion of a dictionary with citations ended on the note that the reader would regard its authors "like enlightened friends, who deliberate with him" and who allow him "the freedom to comply" when judging a proposal appropriately.

As early as 1704, the juxtaposition of an absolutist and an enlightened lexicographer was established. It was completed in the second edition of 1721 with the remark that the work had made much progress thanks to countless corrections and recommendations sent in by learned readers. ${ }^{76}$ Writing anonymously helped to open the door to an egalitarian conception of the author-reader relationship.

For the Jesuit authors of the Dictionnaire de Trévoux, being devoted to enlightened communication did not mean being critical of religion; it rather meant, as they announced in the preface as well, to give ample information on all different religions without judging the theological validity of their beliefs. Following Bayle's judgement (directed against Moréri) that "there is nothing more ridiculous than a dictionary in which one plays the

\footnotetext{
74 Preface in Dictionnaire de Trévoux 1704 (note 8), fol. ei v.

75 Ibid.

76 Preface in Dictionnaire de Trévoux 1721 (note 8), fol. viii.
} 
controversialist", they promised to leave it to the theologians to "refute the errors and to establish the truths" in matters of religion. ${ }^{77}$

On this issue, the encyclopédistes would take a different stance. Diderot and d'Alembert accepted "the democracy of the republic of letters" and equally thanked their well-meaning critics for their suggestions, but for the rest, they rather chose the role of enlightened controversialists with religious beliefs as their preferred target. The polemical vein of their lexicography was reflected as well in their treatment of less well-meaning critics, whom they dismissed as "subaltern censors" and ignorant pedants "with no right and no title" to make a judgement. ${ }^{78}$ Aligning themselves with "the truly illustrious men of our century", they denied that the rest could speak to them on equal terms. Speaking down to opponents suited the overall strategy of Diderot and d'Alembert to fashion the authorship of the Encyclopédie not as "private individuals", but as an alternative academy. Because they lacked the institutional charisma of the French Academy, they had to display and defend their intellectual excellence more aggressively. And even if they were very talented at this, they were only able to prevail thanks to powerful protectors.

When d'Alembert was elected to the Académie française in 1754, he soon got tired of the Encyclopédie and the fights surrounding it; he quit the editorship in the middle of its deepest crisis in $175^{8}$ and from then on reduced his contributions too. A few years later, he took up the preparation of the fifth edition of the Academy's dictionary, together with another encyclopédiste, Marmontel.

\section{CONCLUSION}

Eighteenth-century encyclopaedias and dictionaries played an eminent role in processing, organising and editing knowledge in a time of accelerated knowledge creation. In order to fulfil this role, dictionaries needed to swiftly adapt to the current state of learning. As a genre, they succeeded by gradual innovation from the 1690 and not, as the revolutionary renown of the Encyclopédie and Johnson's Dictionary suggests, by massive breakthroughs. In terms of framing the enlightened scientific dictionary,

77 Preface in Dictionnaire de Trévoux 1704 (note 8), fol. eiii r; Bayle's quotation in id. 1692 (note 63), unpaginated.

78 Jean le Rond d'Alembert, 'Avertissement des Editeurs', in Diderot and d'Alembert 1751-1772 (note 21 ), III: i-xiv: xi. 
Chambers was probably more innovative than Diderot and d'Alembert, and so was Furetière for language dictionaries in comparison to Johnson. The main difference was that Furetière and Chambers did not call equal attention to their originality, hardships and high self-esteem. The public image of dictionaries was to a large extent formed by their authors' selfpromotion.

By acting as universal geniuses, who willingly sacrificed themselves for a thankless task, Johnson and the encyclopédistes made the most of a generally uncomfortable situation for lexicographers. They had to reposition themselves in a learned culture that hailed new knowledge, glorified inventors and called for discoveries, while disparaging the traditional role of lexicographers as compilers. Despite the growing epistemic functionality and public success of dictionaries, dictionary writers faced greater status insecurity because the modern knowledge economy did not provide an adequate role model for their task; instead of revaluing scholars, who occupied complementary positions to scientific inventors and discoverers, it established a dichotomy between original and unoriginal thinkers.

In such a system, lexicographers could only achieve literary glory if they claimed the status of original genius and disguised the actual nature of their scholarship. It was a tactic of self-denial that did not help to raise the profile of lexicographers in the long run. Neither did it contribute to the solution of one of modernity's most persistent self-created problems: how to estimate and integrate forms of knowledge production that do not fit the concept of original invention. 